\title{
Hot-water immersion does not increase postprandial muscle protein synthesis rates during recovery from resistance-type exercise in healthy, young males
}

Citation for published version (APA):

Fuchs, C. J., Smeets, J. S. J., Senden, J. M., Zorenc, A. H., Goessens, J. P. B., van Marken Lichtenbelt, W. D., Verdijk, L. B., \& van Loon, L. J. C. (2020). Hot-water immersion does not increase postprandial muscle protein synthesis rates during recovery from resistance-type exercise in healthy, young males. Journal of Applied Physiology, 128(4), 1012-1022. https://doi.org/10.1152/japplphysiol.00836.2019

Document status and date:

Published: 01/04/2020

DOI:

10.1152/japplphysiol.00836.2019

Document Version:

Publisher's PDF, also known as Version of record

\section{Document license:}

Taverne

Please check the document version of this publication:

- A submitted manuscript is the version of the article upon submission and before peer-review. There can be important differences between the submitted version and the official published version of record.

People interested in the research are advised to contact the author for the final version of the publication, or visit the DOI to the publisher's website.

- The final author version and the galley proof are versions of the publication after peer review.

- The final published version features the final layout of the paper including the volume, issue and page numbers.

Link to publication

\footnotetext{
General rights rights.

- You may freely distribute the URL identifying the publication in the public portal. please follow below link for the End User Agreement:

www.umlib.nl/taverne-license

Take down policy

If you believe that this document breaches copyright please contact us at:

repository@maastrichtuniversity.nl

providing details and we will investigate your claim.
}

Copyright and moral rights for the publications made accessible in the public portal are retained by the authors and/or other copyright owners and it is a condition of accessing publications that users recognise and abide by the legal requirements associated with these

- Users may download and print one copy of any publication from the public portal for the purpose of private study or research.

- You may not further distribute the material or use it for any profit-making activity or commercial gain

If the publication is distributed under the terms of Article 25fa of the Dutch Copyright Act, indicated by the "Taverne" license above, 


\title{
RESEARCH ARTICLE $\mid$ Translational Control of Muscle Mass
}

\section{Hot-water immersion does not increase postprandial muscle protein synthesis rates during recovery from resistance-type exercise in healthy, young males}

\author{
Cas J. Fuchs, ${ }^{1}$ 당 Joey S. J. Smeets, ${ }^{1}$ Joan M. Senden, ${ }^{1}$ Antoine H. Zorenc, ${ }^{1}$ Joy P. B. Goessens, ${ }^{1}$ \\ Wouter D. van Marken Lichtenbelt, ${ }^{2}$ Lex B. Verdijk, ${ }^{1}$ and Luc J. C. van Loon ${ }^{1}$ \\ ${ }^{1}$ Department of Human Biology, NUTRIM School of Nutrition and Translational Research in Metabolism, Maastricht \\ University Medical Centre ${ }^{+}$, Maastricht, The Netherlands; and ${ }^{2}$ Department of Nutrition and Movement Sciences, NUTRIM \\ School of Nutrition and Translational Research in Metabolism, Maastricht University Medical Centre+, Maastricht, The \\ Netherlands
}

Submitted 2 December 2019; accepted in final form 12 March 2020

Fuchs CJ, Smeets JS, Senden JM, Zorenc AH, Goessens JP, van Marken Lichtenbelt WD, Verdijk LB, van Loon LJ. Hot-water immersion does not increase postprandial muscle protein synthesis rates during recovery from resistance-type exercise in healthy, young males. J Appl Physiol 128: 1012-1022, 2020. First published March 19, 2020; doi:10.1152/japplphysiol.00836.2019.-The purpose of this study was to assess the impact of postexercise hot-water immersion on postprandial myofibrillar protein synthesis rates during recovery from a single bout of resistance-type exercise in healthy, young men. Twelve healthy, adult men (age: $23 \pm 1$ y) performed a single bout of resistance-type exercise followed by $20 \mathrm{~min}$ of water immersion of both legs. One leg was immersed in hot water $\left[46^{\circ} \mathrm{C}\right.$ : hot-water immersion (HWI)], while the other leg was immersed in thermoneutral water $\left(30^{\circ} \mathrm{C}\right.$ : $\left.\mathrm{CON}\right)$. After water immersion, a beverage was ingested containing $20 \mathrm{~g}$ intrinsically $\mathrm{L}-\left[1-{ }^{13} \mathrm{C}\right]$-phenylalanine and $\mathrm{L}-\left[1-{ }^{13} \mathrm{C}\right]$-leucine labeled milk protein with $45 \mathrm{~g}$ of carbohydrates. In addition, primed continuous L- $\left[\right.$ ring $\left.{ }_{-}^{2} \mathrm{H}_{5}\right]$-phenylalanine and L-[1$\left.{ }^{13} \mathrm{C}\right]$-leucine infusions were applied, with frequent collection of blood and muscle samples to assess myofibrillar protein synthesis rates in vivo over a 5-h recovery period. Muscle temperature immediately after water immersion was higher in the HWI compared with the CON leg $\left(37.5 \pm 0.1\right.$ vs. $\left.35.2 \pm 0.2^{\circ} \mathrm{C} ; P<0.001\right)$. Incorporation of dietary protein-derived L- $\left[1-{ }^{13} \mathrm{C}\right]$-phenylalanine into myofibrillar protein did not differ between the HWI and CON leg during the 5-h recovery period $(0.025 \pm 0.003$ vs. $0.024 \pm 0.002 \mathrm{MPE} ; P=0.953)$. Postexercise myofibrillar protein synthesis rates did not differ between the HWI and CON leg based upon L-[1- $\left.{ }^{13} \mathrm{C}\right]$-leucine $(0.050 \pm 0.005$ vs. $0.049 \pm 0.002 \% / \mathrm{h} ; P=0.815)$ and $\mathrm{L}-\left[\right.$ ring $\left._{-}{ }^{2} \mathrm{H}_{5}\right]-$ phenylalanine $(0.048 \pm 0.002$ vs. $0.047 \pm 0.003 \% / \mathrm{h} ; P=0.877)$, respectively. Hot-water immersion during recovery from resistancetype exercise does not increase the postprandial rise in myofibrillar protein synthesis rates. In addition, postexercise hot-water immersion does not increase the capacity of the muscle to incorporate dietary protein-derived amino acids in muscle tissue protein during subsequent recovery.

NEW \& NOTEWORTHY This is the first study to assess the effect of postexercise hot-water immersion on postprandial myofibrillar protein synthesis rates and the incorporation of dietary protein-derived amino acids into muscle protein. We observed that hot-water immersion during recovery from a single bout of resistance-type exercise does not further increase myofibrillar protein synthesis rates or aug-

Address for correspondence: L. J. C. van Loon, Dept. of Human Biology, Faculty of Health, Medicine and Life Sciences, Maastricht Univ., P.O. Box 616, 6200 MD Maastricht, The Netherlands (e-mail: 1.vanloon @ maastrichtuniversity.nl). ment the postprandial incorporation of dietary protein-derived amino acids in muscle throughout $5 \mathrm{~h}$ of postexercise recovery.

adaptation; heating; heat stress; hydrotherapy; recovery

\section{INTRODUCTION}

Protein ingestion during recovery from exercise further augments the increase in muscle protein synthesis rates and inhibits muscle protein breakdown, resulting in a positive net muscle protein balance during the acute stages of postexercise recovery $(2,4)$. Consequently, postexercise protein ingestion is widely applied by athletes as a strategy to increase postexercise muscle protein synthesis rates and, as such, to facilitate skeletal muscle reconditioning. On the basis of the observation that ingestion of $20 \mathrm{~g}$ of a high-quality protein source maximally stimulates postexercise muscle protein synthesis rates in healthy, young men $(21,37)$, athletes are advised to ingest 20 $\mathrm{g}$ of protein during recovery from a single bout of resistancetype exercise.

Currently, hot-water immersion (HWI) has been receiving a lot of attention as another effective interventional strategy to facilitate postexercise recovery $(20,34,35)$. HWI has been reported to increase (muscle) tissue temperature and stimulate limb blood flow during recovery from exercise $(26,29)$. HWI during postexercise recovery has also been reported to improve performance recovery, such as attenuating the decrease in jump power (36) and enhancing the recovery of isometric squat force (34). Recently, it was stated that there is ample evidence to suggest that heating can promote muscle cell differentiation and alter the expression of various genes, kinases, and transcription factors involved in muscle remodeling (20). Therefore, postexercise HWI is proposed as an effective tool to facilitate skeletal muscle reconditioning.

Increasing muscle temperature during recovery from exercise may increase enzyme activity and increase skeletal muscle blood flow and, as such, augment nutrient delivery, uptake, and/or subsequent metabolism. In agreement, a previous study in rats has shown that $30 \mathrm{~min}$ of HWI increases phosphorylation of Akt and p70 ribosomal protein S6 kinase (p70S6K), which are considered important mediators of muscle protein synthesis and hypertrophy (38). Furthermore, Kakigi et al. (17) demonstrated that heat stress (applied $20 \mathrm{~min}$ before and during 
isokinetic knee extension exercise) enhanced resistance exercise-induced mammalian target of rapamycin (mTOR) signaling in human skeletal muscle. So far, there have been no studies that have assessed the impact of hot-water immersion on muscle protein synthesis rates. We hypothesized that hotwater immersion after a single bout of resistance-type exercise increases postprandial muscle protein synthesis rates during 5 $\mathrm{h}$ of postexercise recovery in young, healthy males.

In the present study, we combined contemporary stable isotope methodology with the ingestion of specifically produced intrinsically L- $\left[1-{ }^{13} \mathrm{C}\right]$-phenylalanine and L- $\left[1-{ }^{13} \mathrm{C}\right]$-leucine labeled milk protein to assess the effects of postexercise hot-water immersion on myofibrillar protein synthesis rates as well as the incorporation of dietary protein-derived amino acids into muscle tissue protein during $5 \mathrm{~h}$ of postexercise recovery in vivo in healthy, young adults.

\section{METHODS}

Subjects. Twelve healthy, young males (age $23 \pm 1 \mathrm{yr}$ ) participated in this study. All participants were considered recreationally active (exercising $\sim 3$ or 4 times per week for a total duration of $\sim 6 \mathrm{~h}$ ) and were familiar with resistance-type exercise. Subjects' characteristics are presented in Table 1 . Subjects were fully informed of the nature and possible risks of the experimental procedures before their written informed consent was obtained. Participants had no prior history of participating in stable isotope amino acid tracer experiments. This study was approved by the Medical Ethics Committee of the Maastricht University Medical Centre+ (METC 15-3-038) and conformed to the principles outlined in the declaration of Helsinki for use of human subjects and tissue. This study was registered at trialregister.nl as NL6221.

General study design. Each subject participated in one experiment, in which the effect of postexercise hot-water immersion on postprandial muscle protein synthesis was studied after the ingestion of $20 \mathrm{~g}$ intrinsically $\mathrm{L}-\left[1-{ }^{13} \mathrm{C}\right]$-phenylalanine and $\mathrm{L}-\left[1-{ }^{13} \mathrm{C}\right]$-leucine labeled milk protein. The current study was designed to determine the benefits of hot-water immersion to increase postprandial muscle protein synthesis rates during recovery from a single bout of resistance-type exercise in a setting most relevant for athletes. At the start of the experiment, primed continuous L- $\left[\right.$ ring $\left.{ }_{-}^{2} \mathrm{H}_{5}\right]$-phenylalanine and L-[1$\left.{ }^{13} \mathrm{C}\right]$-leucine infusions were applied together with repeated blood sampling during the experimental day. After $1 \mathrm{~h}$ of rest, participants performed $\sim 45 \mathrm{~min}$ of resistance-type exercise training, after which they immersed both legs in water for $20 \mathrm{~min}\left(1 \mathrm{leg}\right.$ at $46^{\circ} \mathrm{C}$ and $1 \mathrm{leg}$ at $30^{\circ} \mathrm{C}$ ). Thereafter, muscle biopsies were collected from both legs,

Table 1. Subjects' characteristics

\begin{tabular}{lc}
\hline \hline & Subjects $(n=12)$ \\
\hline Age, yr & $23 \pm 1$ \\
Body mass, kg & $77.6 \pm 1.8$ \\
Length, m & $1.83 \pm 0.01$ \\
BMI, kg/m² & $23.3 \pm 0.6$ \\
LBM, kg & $62.1 \pm 1.5$ \\
CON leg lean mass, kg & $10.7 \pm 0.3$ \\
HWI leg lean mass, kg & $10.7 \pm 0.3$ \\
Whole body fat mass, kg & $13.0 \pm 1.1$ \\
CON leg fat mass, kg & $2.6 \pm 0.3$ \\
HWI leg fat mass, kg & $2.6 \pm 0.3$ \\
Whole body fat mass, \% & $16.6 \pm 1.2$ \\
Leg press 1RM, kg & $287 \pm 22$ \\
Leg extension 1RM, kg & $127 \pm 6$ \\
\hline
\end{tabular}

Values are expressed as means \pm SE. BMI, body mass index; HWI, hot-water immersion $\left(46^{\circ} \mathrm{C}\right)$ leg; $\mathrm{LBM}$, lean body mass; $1 \mathrm{RM}$, one repetition maximum. $\mathrm{CON}$, thermoneutral water immersion $\left(30^{\circ} \mathrm{C}\right)$ leg. before ingesting $20 \mathrm{~g}$ intrinsically L-[1- $\left.{ }^{13} \mathrm{C}\right]$-phenylalanine- and L-[1$\left.{ }^{13} \mathrm{C}\right]$-leucine-labeled milk protein with $45 \mathrm{~g}$ of glucose (polymers). Subsequent muscle biopsies were taken from the vastus lateralis of both legs after 2 and $5 \mathrm{~h}$ of postexercise recovery.

Pretesting. All subjects participated in a screening session, which was performed at least $1 \mathrm{wk}$ before the experiment. First, subjects' body mass and height were measured, as well as body composition by dual-energy X-ray absorptiometry (DEXA; Discovery A; Hologic, Bedford, MA). The system's software package (Hologic-Apex software version 4.5.3 with viewer software Hologic Physician's viewer, version 7.1) was used to determine whole body and regional lean and fat mass. Subsequently, thigh skinfold thickness was measured using Harpenden skinfold calipers (Baty International, Burgess Hill, England) and divided by 2 to determine the thickness of the thigh subcutaneous fat layer over each participant's vastus lateralis muscle. In addition, participants were familiarized with the exercise equipment and performed maximum strength tests, as determined by their one repetition maximum (1RM) for leg press and knee extension exercise (Table 1). Subjects first performed a 5-min cycling exercise warm-up at $100 \mathrm{~W}$. Thereafter, for both leg press and extension, subjects performed two sets with 10 submaximal or warm-up repetitions to become familiarized with the equipment and to have lifting technique critiqued and corrected. Subjects then performed sets at progressively increasing loads until failing to complete a valid repetition, judged by their inability to complete the full range of motion for an exercise. A 2-min resting period between subsequent attempts was allowed. Finally, participants were familiarized with the water immersion procedure. One leg was immersed in hot water $\left(46^{\circ} \mathrm{C}\right.$ : $\left.\mathrm{HWI}\right)$, while the other leg was immersed in thermoneutral water $\left(30^{\circ} \mathrm{C}\right.$ : $\mathrm{CON}$ ) for a total duration of $20 \mathrm{~min}$. Both legs were immersed to the level of the gluteal fold. The limb heated (HWI) was randomized between subjects' dominant and nondominant leg. For the water immersion setup, two water tanks were used that were completely open at the top and contained a tap at the bottom. This allowed us to set and maintain water temperature (before the 20-min water immersion procedure) by adding (hot) water from the top and remove water from below the tank. During water immersion, temperature was monitored and kept constant and still at $46^{\circ} \mathrm{C}$ in $\mathrm{HWI}$ and $30^{\circ} \mathrm{C}$ in CON.

Diet and activity before the experiment. All subjects received the same standardized dinner $(1,710 \mathrm{~kJ}$, consisting of $20.25 \mathrm{~g}$ protein, $51.75 \mathrm{~g}$ carbohydrate, $7.65 \mathrm{~g}$ dietary fiber, and $11.25 \mathrm{~g}$ fat) the evening before the test day. All volunteers refrained from alcohol and any sort of exhaustive physical labor and/or exercise 2 days before the experimental day.

Experimental protocol. The experimental protocol is outlined in Fig. 1. Each subject participated in one experiment. At the start of the experimental day at 7:30 AM, following an overnight fast, subjects reported to the laboratory. First, a telemetric pill (CorTemp HT150002; HQ) was swallowed with tepid water for continuous measurements of body core temperature until the end of the experiment. In addition, ibuttons (Maxim Integrated Products) were attached to the skin on the left and right upper thigh $(\sim 10 \mathrm{~cm}$ above the patella) for continuous measurements of skin temperature during the entire trial. Thereafter, a Teflon catheter was inserted into an antecubital vein for intravenous isotope tracer infusion, and a second catheter was inserted in a dorsal hand vein of the contralateral arm, which was subsequently placed in a hot-box $\left(60^{\circ} \mathrm{C}\right)$ for arterialized blood sampling. After baseline blood sample collection $(t=-125 \mathrm{~min})$, the plasma phenylalanine and leucine pools were primed with a single intravenous dose of $\mathrm{L}-\left[\right.$ ring $\left._{-}{ }^{2} \mathrm{H}_{5}\right]$-phenylalanine $(2 \mu \mathrm{mol} / \mathrm{kg})$ and $\mathrm{L}-\left[1-{ }^{13} \mathrm{C}\right]$-leucine $(4 \mu \mathrm{mol} / \mathrm{kg})$, respectively. Subsequently, an intravenous infusion of $\mathrm{L}-\left[\right.$ ring $\left._{-}{ }^{2} \mathrm{H}_{5}\right]$-phenylalanine (infusion rate of 0.050 $\left.\mu \mathrm{mol} \cdot \mathrm{kg}^{-1} \cdot \mathrm{min}^{-1}\right)$ and L-[1- $\left.{ }^{13} \mathrm{C}\right]$-leucine $\left(0.100 \mu \mathrm{mol} \cdot \mathrm{kg}^{-1} \cdot \mathrm{min}^{-1}\right)$ was initiated and maintained until the end of the trial using a calibrated IVAC 598 pump (San Diego, CA). After 1 h of supine rest, another arterialized blood sample $(t=-65 \mathrm{~min})$ was obtained. 
Fig. 1. Schematic representation of the experimental design. Participants performed leg press and leg extension exercise followed by water immersion of both legs (1 leg was immersed in $46^{\circ} \mathrm{C}$; the other leg was immersed in thermoneutral water at $30^{\circ} \mathrm{C}$ ) for a total duration of $20 \mathrm{~min}$. After muscle temperature measurements and collection of muscle biopsies from both legs, participants ingested $20 \mathrm{~g}$ of intrinsically labeled milk protein with $45 \mathrm{~g}$ of carbohydrates. Thereafter at $t=120$ and 300 min during postexercise recovery, muscle temperature measurements and muscle biopsies were collected from both legs. Blood samples, skin, and core temperature measurements were collected throughout the infusion day.

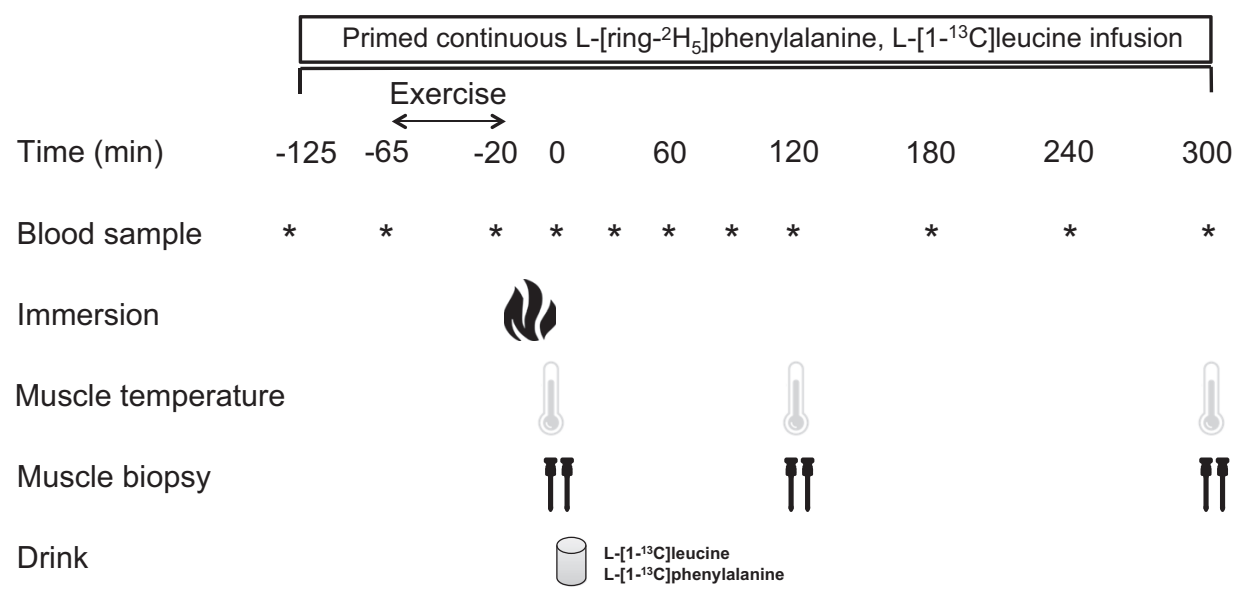

Skin and core temperature
Subsequently, the participants performed a resistance-type exercise session. After a 5-min warm-up on a cycle ergometer at self-selected intensity $(\sim 114 \mathrm{~W})$, the subjects performed 4 sets of 10 repetitions (at $80 \% 1 \mathrm{RM})$ on both the leg press and knee extension exercise. After completion of the exercise bout $(t=-20 \mathrm{~min})$, another arterialized blood sample was obtained before the participants immersed both legs in water for a total duration of $20 \mathrm{~min}$. One leg was immersed in hot water $\left(46^{\circ} \mathrm{C}\right.$ : $\left.\mathrm{HWI}\right)$, while their contralateral leg was immersed in thermoneutral water $\left(30^{\circ} \mathrm{C}\right.$ : $\left.\mathrm{CON}\right)$. Immediately after water immersion, another arterialized blood sample was obtained together with muscle temperature (MT23/5 probe; BAT-10, Physitemp, Clifton, NJ) measurements and muscle biopsies from both legs. The muscle temperature probe was inserted into the biopsy incision before each biopsy was collected from both legs. Immediately afterward, the subjects ingested $20 \mathrm{~g}$ intrinsically L- $\left[1-{ }^{13} \mathrm{C}\right]$-phenylalanine- and $\mathrm{L}-\left[1-{ }^{13} \mathrm{C}\right]$-leucine-labeled milk protein together with $45 \mathrm{~g}$ of carbohydrates (glucose polymers) at $t=0 \mathrm{~min}$. Thereafter, repeated blood samples $(t=30,60,90,120,180,240$, and $300 \mathrm{~min})$ were obtained together with muscle temperature measurements and biopsies from both legs at $t=120$ and $300 \mathrm{~min}$. The muscle biopsies were collected from the middle region of the $\mathrm{M}$. vastus lateralis $(\sim 15 \mathrm{~cm}$ above the patella) with a Bergström needle under local anesthesia (1). The first two biopsies in each leg (at $t=0$ and $120 \mathrm{~min}$ ) were taken from separate incisions. The difference between the separate incisions was $\sim 3 \mathrm{~cm}$ proximal from the previous incision. The last biopsy $(t=300$ min) was collected from the same incision as the biopsy at $t=120$ $\min$. The biopsy at $t=300 \mathrm{~min}$ was collected with the needle inserted in a proximal direction. This method ensured that all biopsy sites were separated by at least $3 \mathrm{~cm}$ to minimize any artifact related to inflammation resulting from multiple biopsies. All biopsy samples were freed from any visible adipose tissue and blood, immediately frozen in liquid nitrogen, and stored at $-80^{\circ} \mathrm{C}$ until subsequent analysis.

Beverage. Subjects received a total beverage volume of $400 \mathrm{~mL}$. The beverage contained $20 \mathrm{~g}$ intrinsically L- $\left[1-{ }^{13} \mathrm{C}\right]$-phenylalanineand $\mathrm{L}-\left[1-{ }^{13} \mathrm{C}\right]$-leucine-labeled milk protein with $45 \mathrm{~g}$ of a vanillaflavored proprietary carbohydrate blend consisting of dextrose and maltodextrin (PepsiCo, Purchase, NY). This was mixed in a bottle with water up to a total volume of $400 \mathrm{~mL}$.

Preparation of tracer. The stable isotope tracers L- $\left[\right.$ ring $\left.{ }^{2} \mathrm{H}_{5}\right]-$ phenylalanine and $\mathrm{L}-\left[1-{ }^{13} \mathrm{C}\right]$-leucine were purchased from Cambridge Isotopes (Andover, MA) and dissolved in $0.9 \%$ saline before infusion (Apotheek A15, Gorinchem, The Netherlands).

Plasma and muscle analysis. Blood samples $(10 \mathrm{~mL})$ were collected in EDTA containing tubes and centrifuged at $1,000 \mathrm{~g}$ and $4{ }^{\circ} \mathrm{C}$ for $10 \mathrm{~min}$. Aliquots of plasma were frozen in liquid nitrogen and stored at $-80^{\circ} \mathrm{C}$ until analysis. Plasma glucose and insulin concentrations were analyzed using commercially available kits (ref. no. A11A01667; glucose HK CP, ABX Diagnostics, Montpellier, France; and ref. no. HI-14K, Millipore, Billerica, MA, respectively). Plasma amino acid concentrations and enrichments were determined by gas chromatography-mass spectrometry analysis (GC-MS; Agilent 7890A GC/5975C; MSD, Wilmington, DE). Specifically, internal standards of $\left[\mathrm{U}^{13} \mathrm{C}_{6}\right]$-leucine, [U- $\left.{ }^{13} \mathrm{C}_{9}{ }^{15} \mathrm{~N}\right]$-phenylalanine, and $\left[\mathrm{U}-{ }^{13} \mathrm{C}_{9}{ }^{15} \mathrm{~N}\right]$ tyrosine were added to the plasma samples. Plasma samples were deproteinized with dry 5-sulfosalicylic acid. Free amino acids were purified using cation exchange chromatography (AG 50W-X8 resin, mesh size: 100-200 $\mu \mathrm{m}$, ionic form: hydrogen; Bio-Rad Laboratories, Hercules, CA). The purified amino acids were converted into tertbutyldimethylsilyl (tert-BDMS) derivatives with $N$-tert-butyldimethylsilyl- $N$-methyltrifluoroacetamide (MTBSTFA) before analysis by GC-MS. The amino acid concentrations and enrichments were determined using selective ion monitoring at mass/charge $(\mathrm{m} / \mathrm{z}) 302$ and 308 for unlabeled and $\left[\mathrm{U}_{-}{ }^{13} \mathrm{C}_{6}\right.$ ] labeled leucine, 336 and 346 for unlabeled and $\left[\mathrm{U}_{-}{ }^{13} \mathrm{C}_{9}{ }^{15} \mathrm{~N}\right]$-labeled phenylalanine, respectively. The plasma leucine and phenylalanine ${ }^{13} \mathrm{C}$ and ${ }^{2} \mathrm{H}$ enrichments were determined at $\mathrm{m} / \mathrm{z}, 302$ and 303 for unlabeled and labeled $\left(1-{ }^{13} \mathrm{C}\right)$ leucine, respectively; $m / z, 336,337$, and 341 for unlabeled and labeled $\left(1-{ }^{13} \mathrm{C}\right.$ and ring $\left.{ }^{-2} \mathrm{H}_{5}\right)$ phenylalanine, respectively. Standard regression curves were applied from a series of known standard enrichment values against the measured values to assess the linearity of the mass spectrometer and to account for any isotope fractionation.

Myofibrillar protein enriched fractions were extracted from $\sim 60 \mathrm{mg}$ of wet muscle tissue by hand-homogenizing on ice using a pestle in a standard extraction buffer $(7 \mu \mathrm{L} / \mathrm{mg})$. The samples were spun at 700

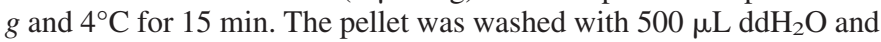
centrifuged at $700 \mathrm{~g}$ and $4^{\circ} \mathrm{C}$ for $10 \mathrm{~min}$. The myofibrillar protein was solubilized by adding $1 \mathrm{~mL}$ of $0.3 \mathrm{M} \mathrm{NaOH}$ and heating at $50^{\circ} \mathrm{C}$ for $30 \mathrm{~min}$ with vortex mixing every $10 \mathrm{~min}$. Samples were centrifuged at $9,500 \mathrm{~g}$ and $4^{\circ} \mathrm{C}$ for $5 \mathrm{~min}$, the supernatant containing the myofibrillar proteins was collected, and the collagen pellet was discarded. Myofibrillar proteins were precipitated by the addition of $1 \mathrm{~mL}$ of $1 \mathrm{M}$ perchloric acid (PCA) and spinning at $700 \mathrm{~g}$ and $4{ }^{\circ} \mathrm{C}$ for $10 \mathrm{~min}$. The myofibrillar protein was washed twice with $70 \%$ ethanol and hydrolyzed overnight in $2 \mathrm{~mL}$ of $6 \mathrm{M} \mathrm{HCL}$ at $110^{\circ} \mathrm{C}$. The free amino acids from the hydrolyzed myofibrillar protein pellet were dried under a nitrogen stream while being heated to $110^{\circ} \mathrm{C}$. The free amino acids were then dissolved in $25 \%$ acetic acid solution, passed over cation exchange AG 50W-X8 resin columns (mesh size: 100-200, ionic form: hydrogen; Bio-Rad Laboratories, Hercules, CA), and eluted with $2 \mathrm{M} \mathrm{NH}_{4} \mathrm{OH}$. The purified amino acids $\left(\mathrm{L}-\left[1-{ }^{13} \mathrm{C}\right]\right.$-phenylalanine 
and L- $\left[1-{ }^{13} \mathrm{C}\right]$-leucine enrichments) were analyzed by gas chromatograph-combustion-isotope ratio mass spectrometer (GC-C-IRMS) analysis. To determine myofibrillar protein $\mathrm{L}-\left[1-{ }^{13} \mathrm{C}\right]$-phenylalanine and L-[1- $\left.{ }^{13} \mathrm{C}\right]$-leucine enrichments by GC-C-IRMS analysis, the purified amino acids were converted into $\mathrm{N}$-ethoxycarbonyl ethyl ester derivatives with ethyl chloroformate (ECF). The derivatives were then measured by GC-C-IRMS (Finnigan MAT 253, Bremen, Germany) using a DB5-MS-column (no. 122-5532; Agilent J+W scientific GC Column, GC Isolink) and monitoring of ion masses 44, 45, and 46. For measurement of L- $\left[\right.$ ring- $\left.{ }^{2} \mathrm{H}_{5}\right]$-phenylalanine enrichment in the myofibrillar protein pools, the eluate was dried, and the purified amino acids were also derivatized into a N-ethoxycarbonyl ethyl ester. The derivatized samples were measured using a gas chromatographyisotope ratio mass spectrometer (MAT 253; Thermo Fisher Scientific, Bremen, Germany) equipped with a pyrolysis oven (gas chromatograph-pyrolysis-isotope ratio mass spectrometer, GC-P-IRMS) using a 70-m DB-17MS column, 5-m precolumn (no. 122-4762; Agilent), and GC-Isolink. Standard regression curves and standards were applied to assess the linearity of the mass spectrometer and to account for isotopic fractionation.

For Western blot analysis, a portion of each muscle sample frozen for biochemical analyses was homogenized in seven volumes Tris buffer (20 mM Tris.HCl, 5 mM EDTA, $10 \mathrm{mM}$ Na-pyrosphosphate, $100 \mathrm{mM} \mathrm{NaF}, 2 \mathrm{mM} \mathrm{Na} \mathrm{VO}_{4}, 1 \%$ Nonident P-40; pH 7.4) supplemented with the following protease and phosphatase inhibitors: aprotinin $10 \mu \mathrm{g} / \mathrm{mL}$, leupeptin $10 \mu \mathrm{g} / \mathrm{mL}$, benzamidine $3 \mathrm{mM}$, and PMSF $1 \mathrm{mM}$. After homogenization, each muscle extract was centrifuged for $10 \mathrm{~min}$ at $10,000 \mathrm{~g}\left(4^{\circ} \mathrm{C}\right)$, and sample buffer was added to the supernatant to final concentrations of $60 \mathrm{mM}$ Tris, $10 \%$ glycerol, 20 $\mathrm{mg} / \mathrm{mL}$ SDS, $0.1 \mathrm{mM}$ DTT, and $20 \mu \mathrm{g} / \mathrm{mL}$ bromophenol blue. The supernatant was then heated for $5 \mathrm{~min}$ at $100^{\circ} \mathrm{C}$ and immediately placed on ice. Immediately before analyses, the muscle extraction sample was warmed to $50^{\circ} \mathrm{C}$ and centrifuged for $1 \mathrm{~min}$ at $1,000 \mathrm{~g}$ (RT). The total amount of sample loaded on the gel was based on protein content. After a Bradford assay, $30 \mu \mathrm{g}$ of protein were loaded in each lane. With the exception of mTOR, protein samples were run on a Criterion Precast TGX 4-20\% gel (Bio-Rad, order no. 567$1094) \pm 90 \mathrm{~min}$ at $150 \mathrm{~V}$ (constant voltage) and transferred onto a Trans-blot Turbo 0.2- $\mu \mathrm{m}$ nitrocellulose membrane (Bio-Rad Order no. $170-4159)$ in $7 \mathrm{~min}$ at $2.5 \mathrm{~A}$ and $25 \mathrm{~V}$. mTOR proteins were run and blotted for $10 \mathrm{~min}$ at $2.5 \mathrm{~A}$ and $25 \mathrm{~V}$ but on a Criterion Precast XT 3-8\% Tris-acetate gel (Bio-Rad, order no. 345-0130). Specific proteins were detected by overnight incubation at $4^{\circ} \mathrm{C}$ on a shaker with specific antibodies in $50 \%$ in PBS Odyssey blocking buffer (Li-Cor Biosciences part no. 927-40000) after blocking for $60 \mathrm{~min}$ at RT in 50\% in PBS Odyssey blocking buffer. Polyclonal primary phospho-specific antibodies, anti-phospho-mTOR $\left(\mathrm{Ser}^{2448}\right)$, antiphospho-S6K1 $\left(\mathrm{Thr}^{389}\right)$, anti-phospho-S6K1 $\left(\mathrm{Thr}^{421} / \mathrm{Ser}^{424}\right)$, antiphospho-ribosomal protein S6 (rpS6) $\left(\mathrm{Ser}^{240} / \mathrm{Ser}^{244}\right)$, anti-phosphorpS6 $\left(\operatorname{Ser}^{235} / \mathrm{Ser}^{236}\right)$, and anti-phospho-eukaryotic translation initiation factor 4E-binding protein 1 (4E-BP1) $\left(\mathrm{Thr}^{37 / 46}\right)$ were purchased from Cell Signaling Technology (Danvers, MA). In addition, antimTOR, anti-S6K1, anti-RS6, anti-4E-BP1, anti-heat shock protein (HSP)27, and anti-HSP70 were also purchased from Cell Signaling Technology (Danvers, MA). Following incubation, membranes were washed three times $10 \mathrm{~min}$ in $0.1 \%$ PBS-Tween 20 and once for 10 min in PBS. Next, samples were incubated on a shaker ( $1 \mathrm{~h}$ at RT) with infrared secondary antibodies, donkey anti-rabbit IRDYE 800 (Rockland, cat. no. 611-732-127, dilution 1:10,000) and donkey anti-mouse IRDYE 800CW (Li-Cor, cat. no. 626-32212, dilution $1: 10,000)$ dissolved in 50\% PBS Odyssey blocking buffer. After a final wash step $(3 \times 10 \mathrm{~min})$ in $0.1 \%$ Tween-20 PBS and once $10 \mathrm{~min}$ in PBS, protein quantification was performed by scanning on an Odyssey Infrared Imaging System (LI-COR Biotechnology, Lincoln, $\mathrm{NE}$ ). All measurements for phospho-specific and total proteins were performed on the same membrane. Ponceau S staining was applied to assess and confirm equal total protein loading. Phosphorylation status as a proxy of activation of the signaling proteins was expressed relative to the total amount of each protein. For heat shock proteins (HSP27 and HSP70), total protein content was expressed relative to Ponceau S staining to correct for the total amount of protein loaded.

Calculations. Ingestion of $\mathrm{L}-\left[1-{ }^{13} \mathrm{C}\right]$-phenylalanine-labeled protein, intravenous infusion of L- $\left[\right.$ ring- $\left._{-}^{2} \mathrm{H}_{5}\right]$-phenylalanine, and blood sample enrichment values were used to calculate total, and exogenous phenylalanine rates of appearance $\left(R_{a}\right)$, and plasma availability of dietary protein-derived phenylalanine that appeared in the systemic circulation as a fraction of total amount of phenylalanine that was ingested $\left(\mathrm{Phe}_{\text {plasma }}\right)$. For these calculations modified Steele's equations (in non-steady-state conditions) were used $(3,6)$. These parameters were calculated as follows:

$$
\begin{gathered}
\text { Total } R_{a}=\frac{F_{i v}-\left[p V \cdot C(t) \cdot \frac{d E_{i v}}{d t}\right]}{E_{i v}(t)} \\
\operatorname{Exo}_{a}=\frac{\operatorname{Total} R_{a} \cdot E_{p o}(t)+\left[p V \cdot C(t) \cdot \frac{d E_{p o}}{d t}\right]}{E_{\text {prot }}} \\
\text { Phe }_{\text {plasma }}=\frac{\mathrm{AUC}_{\text {ExoRa }}}{\text { Phe }_{\text {Prot }}} \cdot 100
\end{gathered}
$$

where $F_{i v}$ is the intravenous tracer infusion rate $\left(\mu \mathrm{mol} \cdot \mathrm{kg}^{-1} \cdot \mathrm{min}^{-1}\right)$, $p V(0.125 \mathrm{~L} / \mathrm{kg})$ is the distribution volume for phenylalanine (3). $C(t)$ is the mean plasma phenylalanine concentration between two consecutive time points. $d E_{i v} / d t$ represents the time-dependent variations of plasma phenylalanine enrichment derived from the intravenous tracer and $E_{i v}(t)$ is the mean plasma phenylalanine enrichment from the intravenous tracer between 2 consecutive time points. ExoR $\mathrm{R}_{\mathrm{a}}$ represents the plasma entry rate of dietary phenylalanine, $E_{p o}(t)$ is the mean plasma phenylalanine enrichment for the ingested tracer, $d E_{p o} / d t$ represents the time-dependent variations of plasma phenylalanine enrichment derived from the oral tracer and $E_{\text {prot }}$ is the L-[1$\left.{ }^{13} \mathrm{C}\right]$-phenylalanine enrichment in the dietary protein. Phe $\mathrm{plasma}_{\text {is }}$ ise percentage of ingested dietary phenylalanine that becomes available in the plasma and is calculated using Phe Prot $_{\text {and }} \mathrm{AUC}_{\text {ExoRa }}$. Phe Prot is the amount of dietary phenylalanine ingested, and $\mathrm{AUC}_{\text {ExoRa }}$ represents the area under the curve (AUC) of $\operatorname{ExoR}_{a}$, which corresponds to the amount of dietary phenylalanine that appeared in the blood over a $5 \mathrm{~h}$ period following ingestion.

The fractional synthesis rate (FSR) of myofibrillar protein was calculated by dividing the increment in enrichment in the product, i.e., protein-bound L- $\left[1-{ }^{13} \mathrm{C}\right]$-leucine or L- $\left[\right.$ ring- $\left.{ }^{2} \mathrm{H}_{5}\right]$-phenylalanine, by the enrichment of the respective precursor amino acid enrichments (i.e., plasma free amino acids). Weighted mean plasma L- $\left[\right.$ ring $\left._{-}{ }^{2} \mathrm{H}_{5}\right]-$ phenylalanine and L- $\left[1-{ }^{13} \mathrm{C}\right]$-leucine enrichments were used as the preferred precursor pools to estimate myofibrillar protein fractional synthesis rates from the continuously infused L- $\left[\right.$ ring- $\left.^{2} \mathrm{H}_{5}\right]$-phenylalanine, and L-[1- $\left.{ }^{13} \mathrm{C}\right]$-leucine tracers. Consequently, myofibrillar FSR was calculated as follows:

$$
\operatorname{FSR}(\% / \mathrm{h})=\left(\frac{E_{m 2}-E_{m 1}}{E_{\text {precursor }} \times t}\right) \times 100
$$

where $E_{m 2}-E_{m 1}$ represents muscle protein-bound L- $\left[\right.$ ring- $\left._{-}{ }^{2} \mathrm{H}_{5}\right]$ phenylalanine or L-[1- $\left.{ }^{13} \mathrm{C}\right]$-leucine. $E_{\text {precursor }}$ represent the average plasma L- $\left[\right.$ ring $\left._{-}{ }^{2} \mathrm{H}_{5}\right]$-phenylalanine or L- $\left[1-{ }^{13} \mathrm{C}\right]$-leucine enrichment during the tracer incorporation period. $t$ indicates the time interval (h) between biopsies.

Statistical analysis. Unless otherwise stated, all data are expressed as means \pm SE. Changes in blood glucose and insulin, plasma amino acid concentrations and enrichments, exogenous phenylalanine $R_{a}$, and core body temperature were analyzed using one-way repeatedmeasures ANOVA with time as within-subjects factor. A two-factor 

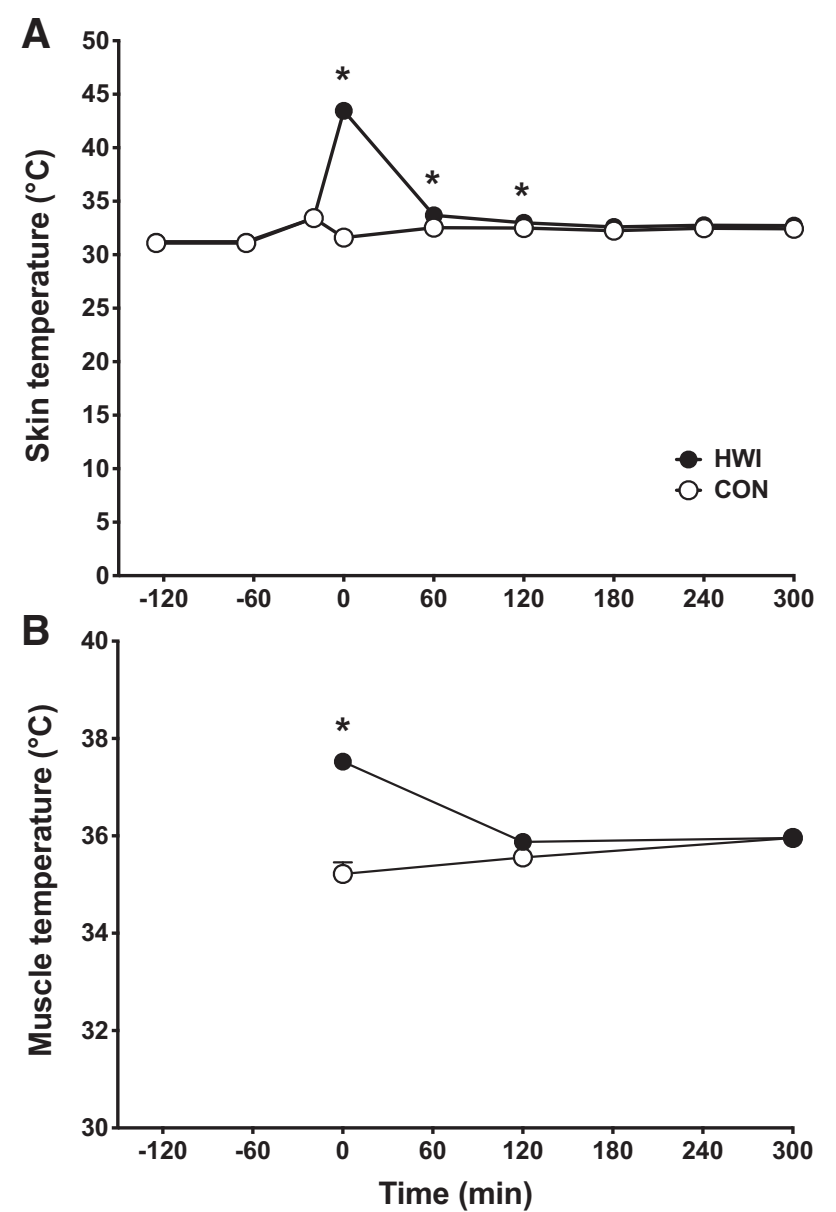

Fig. 2. Skin temperature $(A)$ during the entire experimental protocol and muscle temperature $(B)$ immediately after water immersion $(t=0 \mathrm{~min})$ and $t=$ 120 and 300 min after drink ingestion in CON and HWI in healthy, young men $(n=12)$. Values represent means \pm SE. Data for skin and muscle temperature were analyzed with a two-way repeated-measures ANOVA (time $\times$ treatment) with Bonferonni post hoc testing applied to locate differences. For skin and muscle temperature, time $\times$ treatment interaction, $P<0.001$. *Significantly different $(P<0.05)$ from control $(\mathrm{CON})$. HWI, hot-water immersion $\left(46^{\circ} \mathrm{C}\right)$ leg. $\mathrm{CON}$, thermoneutral water immersion $\left(30^{\circ} \mathrm{C}\right) \mathrm{leg}$.

(treatment $\times$ time) repeated-measures ANOVA was performed for the analysis of L-[1- $\left.{ }^{13} \mathrm{C}\right]$-phenylalanine myofibrillar protein-bound enrichments, skeletal muscle and skin temperature, anabolic signaling, and heat shock protein expression. A Student's paired $t$ test was performed to compare FSR values between the HWI and CON legs. In case of a significant main effect of time or time $\times$ treatment interaction, Bonferroni corrected pairwise comparisons were performed where appropriate. Statistical significance was set at $P<0.05$. All calculations were performed using SPSS (version 24.0; IBM, Armonk, NY).

\section{RESULTS}

Thermoregulatory responses. Core temperature was slightly increased (from $37.0 \pm 0.1^{\circ} \mathrm{C}$ to $37.6 \pm 0.1^{\circ} \mathrm{C}$ ) immediately after water immersion (time effect, $P<0.001$ ). Within $1 \mathrm{~h}$ after water immersion, core temperature returned back to preimmersion values $\left(37.0 \pm 0.1^{\circ} \mathrm{C}\right)$, with no significant differences during the remainder of the postexercise recovery period $(P>0.05)$. Thigh skin temperatures over the entire experiment are shown in Fig. $2 A$. A significant time $\times$ treat- ment interaction was observed for thigh skin temperature $(P<$ 0.001). Thigh skin temperature was significantly higher after exercise $(t=-20 \mathrm{~min})$ in both the HWI and CON leg compared with rest $(t=-60 \mathrm{~min})(P<0.001)$. Only for the HWI leg, thigh skin temperature was significantly increased immediately after water immersion by $\sim 10^{\circ} \mathrm{C}(P<0.001)$. Thigh skin temperature was significantly different between the HWI and CON legs immediately after water immersion up to $2 \mathrm{~h}$ after ingestion of the recovery beverage $(P<0.05)$.

Muscle temperature of both legs after water immersion are shown in Fig. $2 B$. Considering a $\sim 0.5-\mathrm{cm}$ skinfold thickness, the muscle temperature probe $(5 \mathrm{~cm})$ was inserted in the muscle at a depth of $\sim 4.5 \mathrm{~cm}$. A significant time $\times$ treatment interaction was observed for muscle temperature $(P<0.001)$. Muscle temperature did not change significantly over time in the CON leg, but was significantly higher immediately after water immersion ( $t=0 \mathrm{~min})$ compared with $t=120$ and 300 min in the HWI leg $(P<0.001)$. After water immersion $(t=$ $0 \mathrm{~min})$, muscle temperature in the HWI leg was significantly higher $\left(\sim 2.3^{\circ} \mathrm{C}\right)$ when compared with the CON leg $(P<$ 0.001 ). At time points $120 \mathrm{~min}$ and $300 \mathrm{~min}$, muscle temperature was no longer significantly different between legs.

Plasma analyses. Plasma glucose concentrations significantly increased from $t=0$ to $30 \mathrm{~min}$ (from $5.0 \pm 0.2$ to $7.9 \pm 0.3 \mathrm{mmol} / \mathrm{L}$; time effect, $P<0.001)$. At other time points, no significant differences were observed when compared with baseline values $(t=0 \mathrm{~min})$ (data not shown). Plasma insulin concentrations were significantly increased from $t=0(7.4 \pm 0.7 \mathrm{mU} / \mathrm{L})$ to $t=30(73.6 \pm 9.2 \mathrm{mU} / \mathrm{L})$ and $60(26.7 \pm 3.8 \mathrm{mU} / \mathrm{L}) \mathrm{min}$ (time effect, $P<0.001)$. At other time points following drink ingestion, no significant differences were observed when compared with baseline values $(t=$ $0 \mathrm{~min}$ ) (data not shown). Both plasma phenylalanine and leucine concentrations increased following drink ingestion (time effect, $P<0.001)$. Plasma phenylalanine concentrations remained above basal levels $(t=0 \mathrm{~min} ; 60.7 \pm 1.7 \mu \mathrm{mol} / \mathrm{L})$ for $90 \mathrm{~min}(t=90 \mathrm{~min} ; 71.9 \pm 2.8 \mu \mathrm{mol} / \mathrm{L} ; P<0.05)$ and were lower when compared with basal levels at $t=240$ $(52.2 \pm 1.4 \mu \mathrm{mol} / \mathrm{L} ; P<0.001)$ and $300 \mathrm{~min}(53.4 \pm 1.7$ $\mu \mathrm{mol} / \mathrm{L} ; P=0.001)$. Plasma leucine concentrations were significantly higher than basal levels $(t=0 \mathrm{~min} ; 127 \pm 5$ $\mu \mathrm{mol} / \mathrm{L}$ ) during the entire 5 -h recovery period (apart from $t=$ $240 \mathrm{~min} ; 143 \pm 5 \mu \mathrm{mol} / \mathrm{L} ; P=0.069)$.

During the postabsorptive period, plasma L-[ring- $\left.{ }^{2} \mathrm{H}_{5}\right]$-phenylalanine (Fig. 3A) and L-[1-13 C]-leucine (Fig. 3B) enrichments remained in a steady state. Following drink ingestion, plasma L-[ring- ${ }^{2} \mathrm{H}_{5}$ ]-phenylalanine enrichments were significantly lower for the first $90 \mathrm{~min}$, not significantly different (compared with baseline) at $t=120$ and $180 \mathrm{~min}$, and significantly higher at $t=240$ and $300 \mathrm{~min}$ (time effect, $P<0.001$ ). Plasma L- $\left[1-{ }^{13} \mathrm{C}\right]$-leucine enrichments increased in response to drink ingestion (time effect, $P<0.001$ ) and remained at an elevated steady state of $\sim 6.0-8.0$ mole percent excess (MPE) for the duration of the 5 -h postprandial period. Following drink ingestion, plasma L-[1-13 $\mathrm{C}]$-phenylalanine enrichments increased rapidly (time effect, $P<0.001$ ) from 0 to $14.3 \pm 0.4$ MPE after $30 \mathrm{~min}$ and declined thereafter, albeit remaining elevated above fasting levels for the remainder of the postprandial period (Fig. 3C).

Ingestion of the $20 \mathrm{~g}$ intrinsically labeled milk protein resulted in a rapid rise in exogenous phenylalanine appearance 

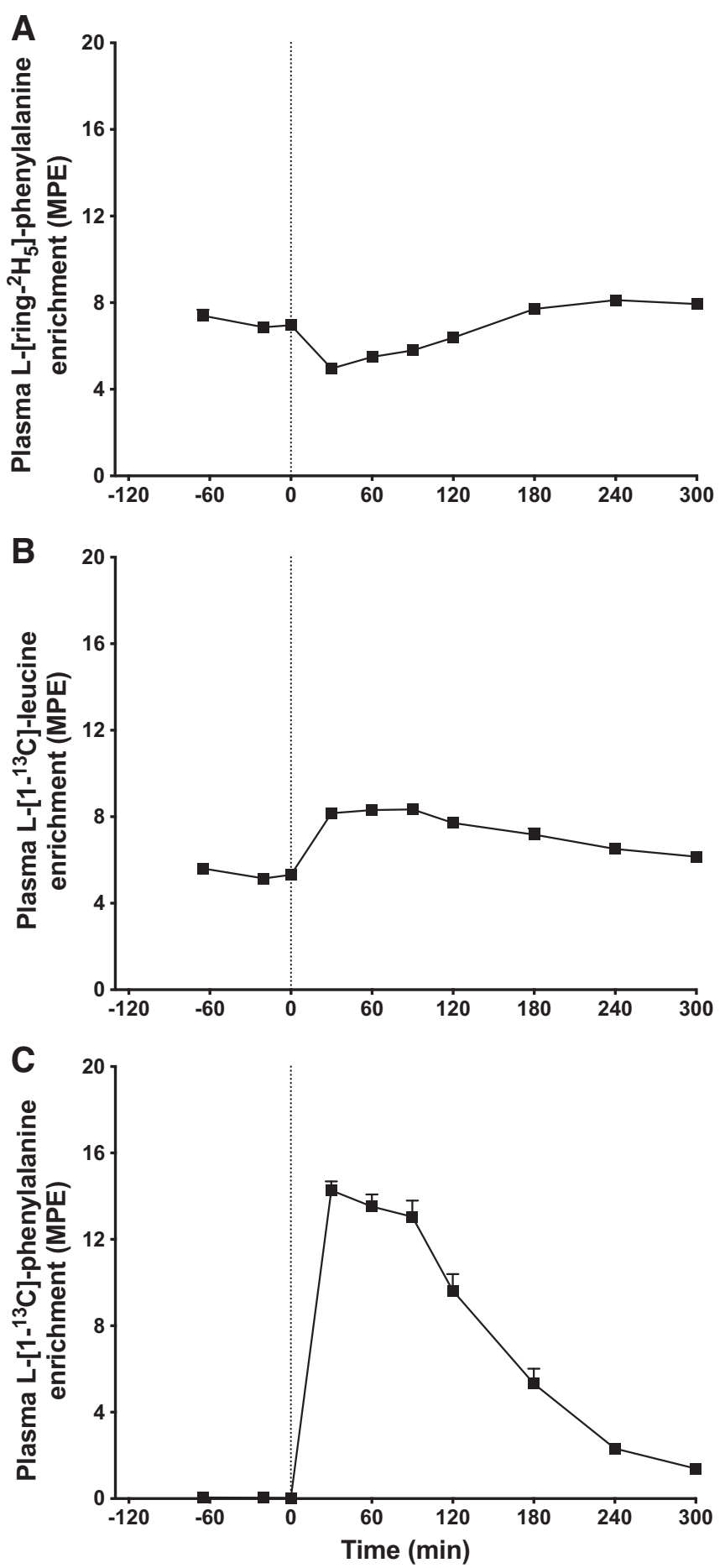

Fig. 3. Plasma L-[ring- $\left.{ }^{2} \mathrm{H}_{5}\right]$-phenylalanine $(A)$, L- $\left[1-{ }^{13} \mathrm{C}\right]$-leucine $(B)$, and $\mathrm{L}-\left[1-{ }^{13} \mathrm{C}\right]$-phenylalanine $(C)$ enrichments in MPE in healthy, young men $(n=$ 12). The dotted line represents the ingestion of $20 \mathrm{~g}$ intrinsically labeled milk protein with $45 \mathrm{~g}$ carbohydrate (at $t=0 \mathrm{~min}$ ). Values represent means $\pm \mathrm{SE}$. Data were analyzed with a one-way repeated measures ANOVA with Bonferonni post hoc testing applied to locate differences. For all panels: time effect, $P<0.001$.

rates (time effect, $P<0.001$; Fig. 4), and this remained significantly elevated over the entire postprandial recovery period compared with baseline ( $t=0 \mathrm{~min})$. Over the entire 5 -h period, $14.7 \pm 0.3 \mathrm{~g}(74 \pm 2 \%)$ of the ingested protein-derived amino acids had been released into the circulation.
Muscle tracer analysis. Myofibrillar protein FSR based on intravenous L-[ ring $\left.{ }^{2} \mathrm{H}_{5}\right]$-phenylalanine infusion with plasma L- $\left[\right.$ ring $\left.^{2}{ }^{2} \mathrm{H}_{5}\right]$-phenylalanine enrichments as precursor pool (Fig. 5A) or intravenous L-[1-13 $\mathrm{C}]$-leucine infusion combined with intrinsically $\mathrm{L}-\left[1-{ }^{13} \mathrm{C}\right]$-leucine-labeled protein ingestion with plasma L- $\left[1-{ }^{13} \mathrm{C}\right]$-leucine enrichments as precursor pool (Fig. 5B) are displayed in Fig. 5. Myofibrillar protein FSR as calculated over $0-2 \mathrm{~h}$ did not differ between the HWI and $\mathrm{CON}$ leg based on the L- $\left[\right.$ ring $\left._{-}{ }^{2} \mathrm{H}_{5}\right]$-phenylalanine tracer $(0.065 \pm 0.002$ vs. $0.066 \pm 0.004 \% / \mathrm{h}$, respectively; $P=$ $0.704)$ and the L- $\left[1-{ }^{13} \mathrm{C}\right]$-leucine tracer $(0.065 \pm 0.008$ vs. $0.062 \pm 0.006 \% / \mathrm{h}$, respectively; $P=0.616$ ). In addition, myofibrillar protein FSR, as calculated over the entire 5-h postprandial period, also did not differ between the HWI and CON leg based on the L- $\left[\right.$ ring- $\left.{ }^{2} \mathrm{H}_{5}\right]$-phenylalanine tracer $(0.048 \pm$ 0.002 vs. $0.047 \pm 0.003 \% / \mathrm{h}$, respectively; $P=0.877$ ) as well as the $\mathrm{L}-\left[1-{ }^{13} \mathrm{C}\right]$-leucine tracer $(0.050 \pm 0.005$ vs. $0.049 \pm$ $0.002 \% / \mathrm{h}$, respectively; $P=0.815$ ).

Myofibrillar L- $\left[1-{ }^{13} \mathrm{C}\right]$-phenylalanine enrichments are displayed in Fig. 6. A significant time effect was found $(P<$ $0.001)$. However, no significant treatment effect or time $\times$ treatment interaction was observed $(P>0.05)$, indicating higher myofibrillar L- $\left[1-{ }^{13} \mathrm{C}\right]$-phenylalanine enrichments at $5 \mathrm{~h}$ vs. $2 \mathrm{~h}$ for both the CON and HWI leg, with no differences between legs.

Muscle molecular signaling. The phosphorylation status (ratio of phosphorylated protein to total protein) of key proteins involved in the initiation of muscle protein synthesis are presented in Fig. 7, $A-F$. No significant differences were observed for muscle mTOR (Ser-2448) phosphorylation status (Fig. 7A). A significant time effect, treatment effect, and time $\times$ treatment interaction was observed for muscle p70S6K (Thr-389) phosphorylation status $(P<0.05$; Fig. 7B). Muscle p70S6K (Thr-389) phosphorylation status was significantly increased from 0 to $2 \mathrm{~h}(P=0.007)$ in the HWI leg and significantly decreased from 2 to $5 \mathrm{~h}(P<0.01)$ in both the HWI and CON leg. The phosphorylation status was significantly different between treatments at all time points $(P<$

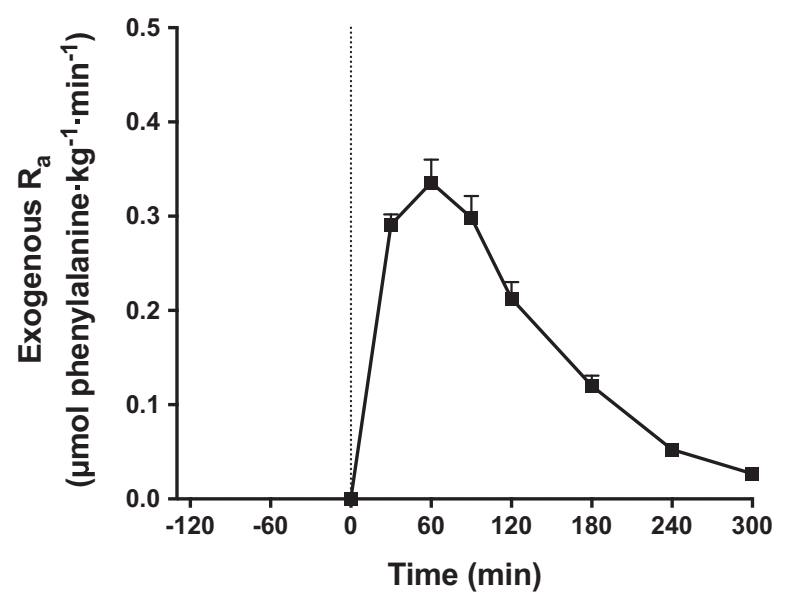

Fig. 4. Exogenous phenylalanine rate of appearance $\left(R_{a}\right)$ in healthy, young men $(n=12)$. The dotted line represents the ingestion of $20 \mathrm{~g}$ of intrinsically labeled milk protein with $45 \mathrm{~g}$ carbohydrate (at $t=0 \mathrm{~min}$ ). Values represent means $\pm \mathrm{SE}$. Data were analyzed with a one-way repeated-measures ANOVA with Bonferonni post hoc testing applied to locate differences. Time effect, $P<0.001$. 
A

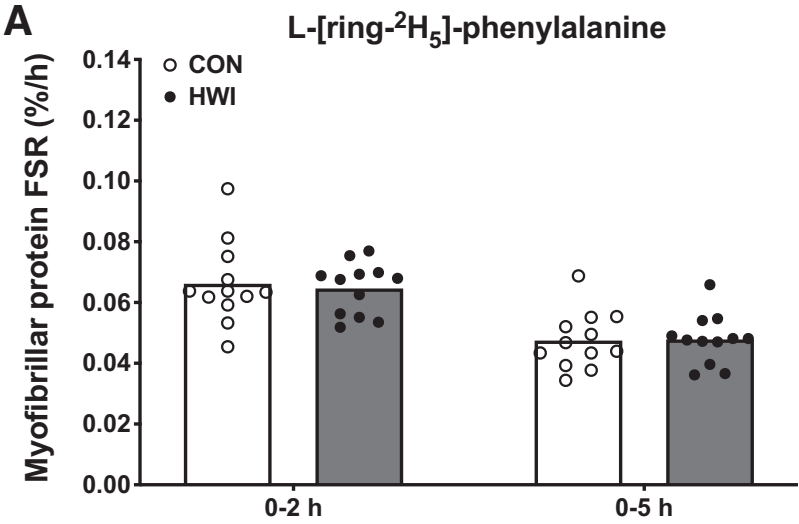

B

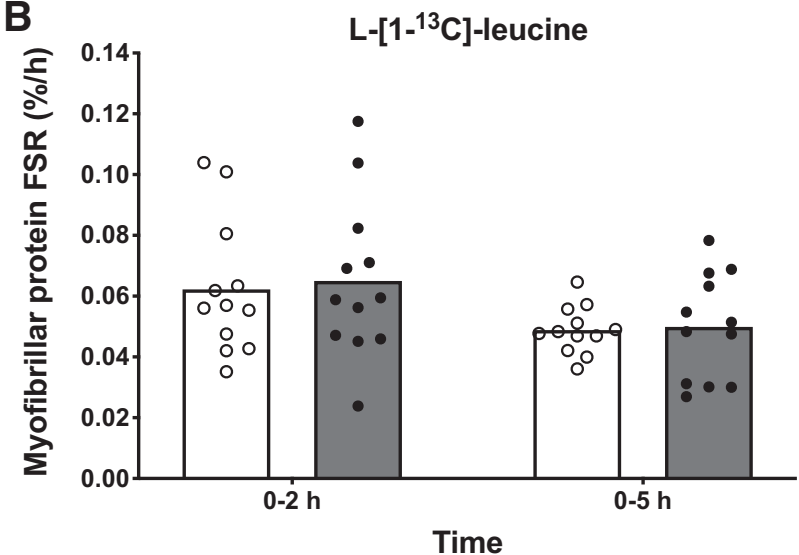

Fig. 5. Myofibrillar protein FSRs, as calculated with L-[ring- $\left.{ }^{2} \mathrm{H}_{5}\right]$-phenylalanine $(\mathrm{A})$ or L- $\left[1-{ }^{13} \mathrm{C}\right]$-leucine (B) as tracer during $5 \mathrm{~h}$ of postexercise recovery with the ingestion of $20 \mathrm{~g}$ of intrinsically labeled milk protein with $45 \mathrm{~g}$ of carbohydrate in healthy, young men $(n=12)$. Bars are means, and dots represent individual values. Data were analyzed with a paired Student's $t$ test. FSR, fractional synthetic rate. HWI, hot-water immersion $\left(46^{\circ} \mathrm{C}\right)$ leg. $\mathrm{CON}$, thermoneutral water immersion $\left(30^{\circ} \mathrm{C}\right)$ leg.

0.05). At $t=0 \mathrm{~h}$, the $\mathrm{CON}$ leg was significantly higher compared with the HWI leg $(P=0.031)$. At both $t=2$ and 5 $\mathrm{h}$, the HWI leg was significantly higher compared with the CON leg $(P<0.05)$. A significant time effect was found for muscle p70S6K (Thr-421/Ser-424) phosphorylation status $(P<0.001$; Fig. $7 C)$. No significant treatment effect or time $\times$ treatment interaction was observed for muscle p70S6K (Thr421/Ser-424) phosphorylation status. No significant differences were observed for muscle rpS6 (Ser-240/244) phosphorylation status (Fig. 7D). A significant time effect was found for muscle rpS6 (Ser-235/236) phosphorylation status $(P=0.040$; Fig. $7 E)$, with no significant treatment effect or time $\times$ treatment interaction observed. No significant differences were observed for muscle 4E-BP1 (Thr-37/46) phosphorylation status (Fig. $7 F$ ). Total protein content of HSP27 and HSP70 (expressed relative to Ponceau $\mathrm{S}$ staining) is presented in Fig. $8, A$ and $B$. No significant differences over time were observed for both HSP27 (Fig. 8A) and HSP70 (Fig. 8B) contents.

\section{DISCUSSION}

In the present study, we assessed the impact of postexercise hot-water immersion on postprandial myofibrillar protein synthesis rates during recovery from resistance-type exercise.
Hot-water immersion transiently increased skin and muscle temperature, but it did not further increase postprandial myofibrillar protein synthesis rates or augment the incorporation of dietary protein-derived amino acids in muscle tissue protein during $5 \mathrm{~h}$ of postexercise recovery.

It has been well established that protein intake increases postexercise muscle protein synthesis rates $(16,21,24,31)$, thereby improving postexercise skeletal muscle reconditioning. It has previously been reported that ingestion of $20 \mathrm{~g}$ of a high-quality protein maximizes postexercise muscle protein synthesis rate during recovery from lower body resistance exercise $(21,37)$. Therefore, in line with everyday practice, our (recreational) athletes were provided with $20 \mathrm{~g}$ (of intrinsically labeled milk) protein and $45 \mathrm{~g}$ of carbohydrates following cessation of exercise. In line with previous work $(7-9,13,32)$, we showed that the dietary protein-derived amino acids were effectively being taken up and released in the systemic circulation (Fig. 4), thereby providing ample precursors to support the postexercise increase in myofibrillar protein synthesis. In total, more than $70 \%$ of the ingested protein-derived amino acids were released in the circulation, thereby strongly increasing plasma amino acid concentrations.

Hydrotherapy is a popular recovery strategy that is applied by many athletes to support their postexercise recovery (35). Two popular hydrotherapy strategies are cold-water immersion (CWI) and hot-water immersion (HWI) (35). It has been reported that CWI is more effective in improving markers of acute postexercise recovery, such as reducing delayed onset muscle soreness (DOMS), lowering limb swelling, and assisting in performance recovery compared with $\mathrm{HWI}(18,23$, 33-35). However, CWI has been shown to lower tissue temperature and reduce blood flow $(12,19)$, thereby reducing the incorporation of dietary protein-derived amino acids into muscle protein and attenuating the postexercise increase in muscle protein synthesis rates by $\sim 20 \%$ (7). Consequently, athletes aiming to improve postexercise muscle (re)conditioning are generally not recommended to apply CWI during recovery from exercise. In contrast, it has been hypothesized that postexercise HWI, by stimulating blood flow and/or increasing mus-

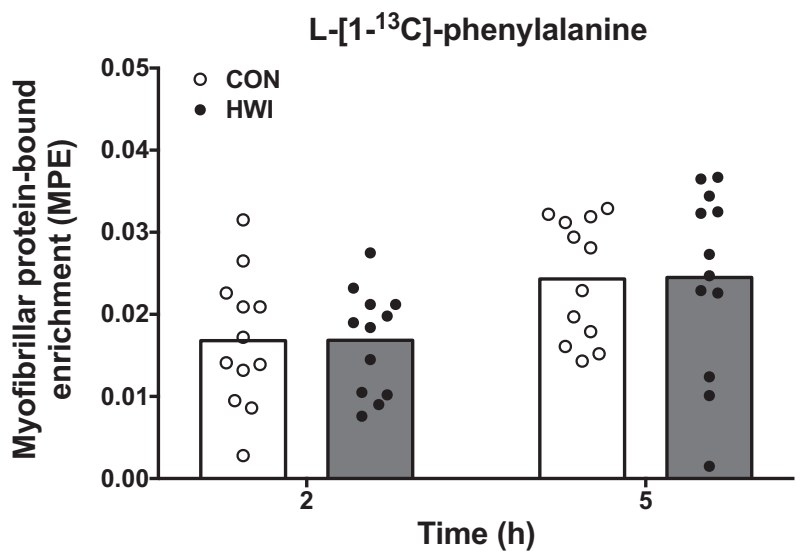

Fig. 6. L- $\left[1-{ }^{13} \mathrm{C}\right]$-phenylalanine incorporation into myofibrillar protein after drink ingestion with intrinsically labeled L- $\left[1-{ }^{13} \mathrm{C}\right]$-phenylalanine in healthy, young men $(n=12)$. Bars are means, and dots represent individual values. Data were analyzed with a two-way repeated-measures ANOVA (time $\times$ treatment). MPE, mole percent excess. HWI, hot-water immersion $\left(46^{\circ} \mathrm{C}\right) \mathrm{leg}$. $\mathrm{CON}$, thermoneutral water immersion $\left(30^{\circ} \mathrm{C}\right) \mathrm{leg}$. 

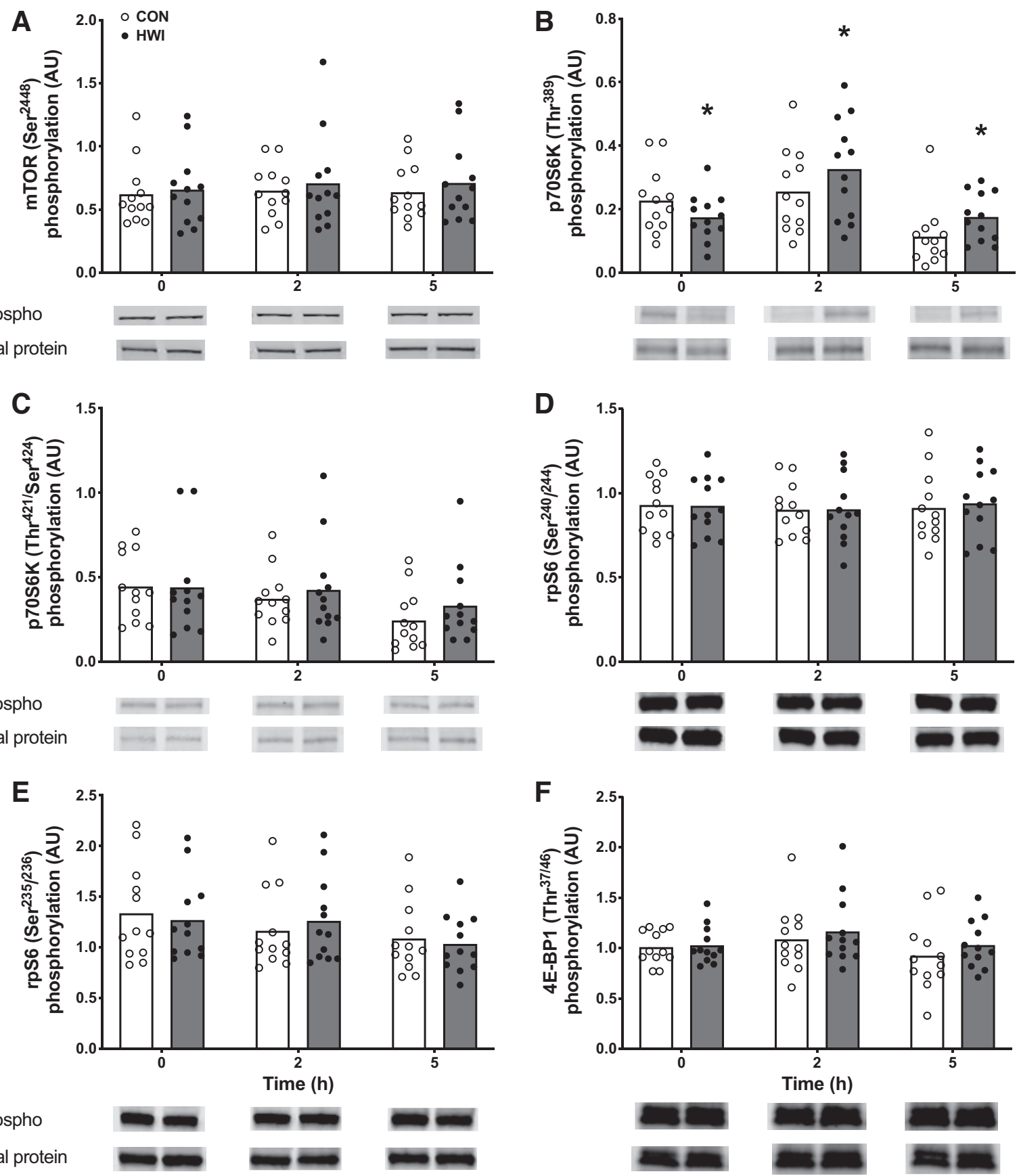

Fig. 7. Skeletal muscle phosphorylation status (ratio of phosphorylated protein to total protein) of mTOR (Ser-2448) (A), p70S6K (Thr-389) (B), p70S6K $(\mathrm{Thr}-421 / \mathrm{Ser}-424)(C), \mathrm{rpS} 6(\operatorname{Ser}-240 / 244)(D), \operatorname{rpS} 6(\operatorname{Ser}-235 / 236)(E)$, and 4E-BP1 (Thr-37/46) $(F)$ immediately after postexercise water immersion $(t=0 \mathrm{~h})$ and after ingestion of 20-g intrinsically labeled milk protein with $45 \mathrm{~g}$ of carbohydrate $(t=2$ and $5 \mathrm{~h})$ in healthy, young men $(n=12)$. Bars are means, and dots represent individual values. Data were analyzed with a repeated-measures ANOVA (time $\times$ treatment) with Bonferonni post hoc testing applied to locate differences. $A$ : no significant effects. $B$ : significant time effect, treatment effect, and time $\times$ treatment interaction $(P<0.05)$. $C$ : significant time $(P<0.001)$ effect. $D$ : no significant effects. $E$ : significant time $(P=0.040)$ effect. $F$ : no significant effects. *Significantly different $(P<0.05)$ from CON. HWI, hot-water immersion $\left(46^{\circ} \mathrm{C}\right)$ leg. $\mathrm{CON}$, thermoneutral water immersion $\left(30^{\circ} \mathrm{C}\right)$ leg.

cle tissue temperature, can augment muscle protein synthesis during recovery from exercise.

In the current study, exercise was followed by immersing one leg in hot water $\left(46^{\circ} \mathrm{C}\right)$, while the contralateral leg was immersed in thermoneutral water $\left(30^{\circ} \mathrm{C}\right)$ for $20 \mathrm{~min}$. This short hot-water immersion regimen was selected on the basis of everyday practice by athletes, as well as previous studies (35) with the (hot) water temperature being selected on the basis of what was perceived as tolerable for $20 \mathrm{~min}$. Hot-water immersion increased skin $\left(\sim 10^{\circ} \mathrm{C}\right)$, as well as muscle $\left(\sim 2.3^{\circ} \mathrm{C}\right)$ temperature, after which levels approximately returned to basal values within the first $120 \mathrm{~min}$ of postexercise recovery (Fig. 2). Despite the observed increases in skin and muscle temperature, postexercise HWI did not modulate postprandial myofibrillar protein synthesis rates (Fig. 5) or affect the incorporation of dietary protein-derived amino acids in 

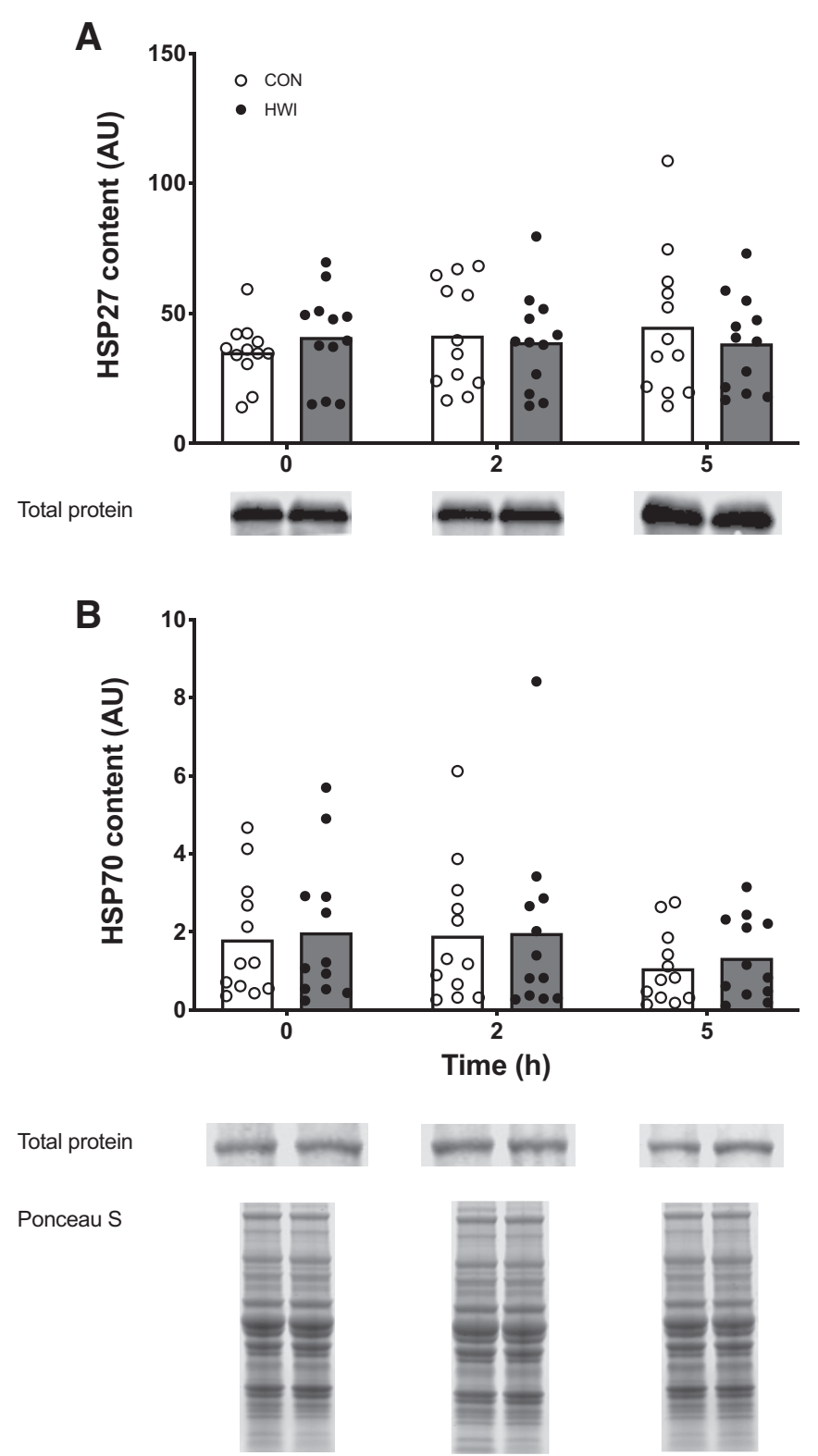

Fig. 8. Skeletal muscle heat shock protein content (expressed relative to Ponceau S staining) of HSP27 $(A)$ and HSP70 $(B)$ immediately after postexercise water immersion $(t=0 \mathrm{~h})$ and after ingestion of $20 \mathrm{~g}$ of intrinsically labeled milk protein with $45 \mathrm{~g}$ of carbohydrate $(t=2$ and $5 \mathrm{~h})$ in healthy, young men $(n=12)$. Bars are means, and dots represent individual values. Data were analyzed with a repeated-measures ANOVA (time $\times$ treatment). No significant effects over time or between treatments were observed. HWI, hot-water immersion $\left(46^{\circ} \mathrm{C}\right)$ leg. $\mathrm{CON}$, thermoneutral water immersion $\left(30^{\circ} \mathrm{C}\right)$ leg.

muscle tissue during the early or later stages of postexercise recovery (Fig. 6).

The current findings seem to be at odds with previous suggestions (based on anabolic signaling responses) that heat stress may increase muscle protein synthesis rates $(17,38)$. It has previously been shown in rodents that the application of 30 min of local heat stress (HWI), activates the mTOR pathway by increasing the phosphorylation of Akt (at Ser-473) and p70S6K (at Thr-389) (38). In line with this, Kakigi et al. (17) showed that local heat stress performed 20 min before and during resistance exercise enhanced mTOR signaling in muscle tissue in humans. However, those studies did not perform hot-water immersion during recovery from exercise. In the present study, we also assessed the phosphorylation status of several molecular markers that are important in the regulation of myofibrillar protein synthesis during postexercise recovery (Fig. 7). We extend on previous findings by showing that p70S6K phosphorylation at Thr-389 was lower immediately after HWI, but increased at 2 and $5 \mathrm{~h}$ into postexercise recovery when compared with the CON leg (Fig. $7 B$ ). The reason that p70S6K phosphorylation at Thr-389 was lower in the HWI leg immediately after postexercise water immersion when compared with the CON leg remains unclear. However, it is interesting to note that we have previously shown that p70S6K phosphorylation at Thr-389 was higher immediately after postexercise $\mathrm{CWI}\left(8^{\circ} \mathrm{C}\right)$ when compared with thermoneutral water immersion $\left(30^{\circ} \mathrm{C}\right)$ for $20 \mathrm{~min}(7)$. Therefore, muscle temperature seems to modulate p70S6K phosphorylation at Thr-389. The fact that p70S6K phosphorylation at Thr-389 was increased at 2 and $5 \mathrm{~h}$ in the postexercise recovery period in the HWI compared with the CON leg may have compensated for the lower phosphorylation status observed immediately after water immersion $(t=0 \mathrm{~h})$. Other molecular markers did not show differences between the HWI and CON leg (Fig. 7). As evidence suggests that heat stress can elicit protective effects to assist postexercise recovery and adaptation by increasing heat shock protein (HSP) expression (20), we also measured HSP27 and HSP70 expression. We did not observe any differences in both HSPs between the HWI and CON leg during $5 \mathrm{~h}$ of postexercise recovery (Fig. 8). This could potentially be explained by the fact that $5 \mathrm{~h}$ of postexercise recovery is not sufficient to pick up differences, as it is possible that longer postheating durations may be necessary to pick up changes in HSPs. Alternatively, our heating strategy may not have been sufficient to induce changes in HSPs. Overall, these observations seem to agree with the absence of differences in muscle protein synthesis rates between the HWI and the CON leg.

Our findings indicate that athletes seeking to accelerate postexercise muscle reconditioning do not benefit from the application of hot-water immersion during postexercise recovery. These findings seem to agree with Stadnyk et al. (28), who did not observe greater gains in leg lean mass or strength during more prolonged resistance-type exercise training when applying heating. In contrast, two studies by Goto et al. showed that heating applied with (10) or even without (11) exercise training over a period of $10 \mathrm{wk}$ increased gains in muscle cross-sectional area and strength $(10,11)$. The apparent discrepancy between these studies may be attributed to differences in 1) the applied exercise protocol, 2) heat modalities (i.e., heat pads vs. heat- and steam-generating sheets) and duration, and 3) the applied methods to assess muscle size. However, it is interesting to note that the study by Stadnyk et al. (28) performed exercise at a relatively high intensity (4 sets of 8 repetitions at 70\% 1RM for 2-3 days a week), whereas the studies by Goto et al. performed low-intensity exercise training (3 sets of 30 repetitions against a resistance of less than $30 \mathrm{RM}$ for 4 days a week) (10) or did not perform exercise at all (11) over a $10-w k$ intervention period. Therefore, it could be speculated that heat stress may increase gains in muscle mass and strength when applied during low(er)-intensity exercise or when applied without exercise throughout a more prolonged intervention period, whereas heat stress performed around 
high-intensity exercise training does not (further) augment gains in muscle mass and strength. In the present study, we clearly show that short, hot-water immersion applied after a single bout of more intense resistance-type exercise $(80 \%$ $1 \mathrm{RM}$ ) does not further augment muscle protein synthesis rates in (recreational) athletes consuming ample protein during $5 \mathrm{~h}$ of postexercise recovery.

In the current study, we observed a transient increase in muscle tissue temperature after HWI. If we would extrapolate our data on the basis of previous work (25), tissue temperature would likely have returned to basal values within $\sim 30$ min after exercise. Therefore, it could be speculated that our heating protocol $\left(20 \mathrm{~min}\right.$ of $\mathrm{HWI}$ at $\left.46^{\circ} \mathrm{C}\right)$ did not elicit a sufficient, continued increase in muscle temperature and that a stronger and/or more prolonged heating protocol may have been more potent. In previous pilot work, we established that HWI with water at a temperature of $\sim 46^{\circ} \mathrm{C}$ is the maximum tolerable temperature when applied for $20 \mathrm{~min}$. With this protocol, we observed a muscle temperature of $\sim 37.5^{\circ} \mathrm{C}$ in the HWI leg, which was $\sim 2.3^{\circ} \mathrm{C}$ higher compared with the CON leg. Previous studies have shown similar increases in intramuscular temperature when applying other heating modalities, such as heat pads and hot water-perfused limb cuffs $(5,27,39)$. Muscle temperature may be further increased (up to $\sim 40^{\circ} \mathrm{C}$ ) by applying diathermy $(14,15)$. However, it should be noted that the application of diathermy for postexercise recovery may not be practical for athletes, as this is typically applied very locally with only a small amount of muscle being heated. Nonetheless, further research may be warranted to investigate the impact of other heating strategies on recovery during (low-intensity) exercise. Such future studies should focus on local, rather than whole body, heating strategies as prolonged whole body heat stress can be detrimental for other important aspects of postexercise muscle recovery, such as glycogen synthesis (22). In addition, future studies may want to address the impact of prolonged (postexercise) heating on the synthesis rates of more specific protein subfractions, such as mitochondrial proteins $(14,15,30)$.

In conclusion, short hot-water immersion during recovery from resistance-type exercise does not increase postprandial myofibrillar protein synthesis rates or augment the capacity of the muscle to use dietary protein-derived amino acids for de novo myofibrillar protein accretion. Postexercise hot-water immersion, as often applied in practice, does not seem to enhance the skeletal muscle adaptive response to exercise training and, thus, would unlikely improve skeletal muscle conditioning.

\section{ACKNOWLEDGMENTS}

We would like to acknowledge Lieke de Wit, Denise Tan and Annemie P. Gijsen for their (technical) assistance and the enthusiastic support of the subjects who volunteered to participate in this experiment.

This study was registered at trialregister.nl as NL6221.

\section{GRANTS}

This study was internally funded by Maastricht University.

\section{DISCLOSURES}

No conflicts of interest, financial or otherwise, are declared by the authors.

\section{AUTHOR CONTRIBUTIONS}

C.J.F. and L.J.v.L. conceived and designed research; C.J.F. and J.S.S. performed experiments; C.J.F., J.M.S., A.H.Z., and J.P.G. analyzed data;
C.J.F. and L.J.v.L. interpreted results of experiments; C.J.F. prepared figures; C.J.F. drafted manuscript; C.J.F., J.S.S., J.M.S., A.H.Z., J.P.G., W.D.v.M.L., L.B.V., and L.J.v.L. edited and revised manuscript; C.J.F., J.S.S., J.M.S., A.H.Z., J.P.G., W.D.v.M.L., L.B.V., and L.J.v.L. approved final version of manuscript.

\section{REFERENCES}

1. Bergström J. Percutaneous needle biopsy of skeletal muscle in physiological and clinical research. Scand J Clin Lab Invest 35: 609-616, 1975. doi:10.3109/00365517509095787.

2. Biolo G, Tipton KD, Klein S, Wolfe RR. An abundant supply of amino acids enhances the metabolic effect of exercise on muscle protein. Am J Physiol Endocrinol Metab 273: E122-E129, 1997. doi:10.1152/ajpendo. 1997.273.1.E122.

3. Boirie Y, Gachon P, Corny S, Fauquant J, Maubois JL, Beaufrère B. Acute postprandial changes in leucine metabolism as assessed with an intrinsically labeled milk protein. Am J Physiol Endocrinol Metab 271: E1083-E1091, 1996. doi:10.1152/ajpendo.1996.271.6.E1083.

4. Børsheim E, Tipton KD, Wolf SE, Wolfe RR. Essential amino acids and muscle protein recovery from resistance exercise. Am J Physiol Endocrinol Metab 283: E648-E657, 2002. doi:10.1152/ajpendo.00466.2001.

5. Cheng AJ, Willis SJ, Zinner C, Chaillou T, Ivarsson N, Ørtenblad N, Lanner JT, Holmberg HC, Westerblad H. Post-exercise recovery of contractile function and endurance in humans and mice is accelerated by heating and slowed by cooling skeletal muscle. J Physiol 595: 7413-7426, 2017. doi:10.1113/JP274870.

6. Dangin M, Guillet C, Garcia-Rodenas C, Gachon P, BouteloupDemange $\mathrm{C}$, Reiffers-Magnani $\mathrm{K}$, Fauquant $\mathrm{J}$, Ballèvre $\mathrm{O}$, Beaufrère B. The rate of protein digestion affects protein gain differently during aging in humans. J Physiol 549: 635-644, 2003. doi:10.1113/jphysiol. 2002.036897.

7. Fuchs CJ, Kouw IWK, Churchward-Venne TA, Smeets JSJ, Senden JM, Lichtenbelt WDVM, Verdijk LB, van Loon LJC. Postexercise cooling impairs muscle protein synthesis rates in recreational athletes. $J$ Physiol 598: 755-772, 2020. doi:10.1113/JP278996.

8. Gorissen SH, Burd NA, Hamer HM, Gijsen AP, Groen BB, van Loon LJ. Carbohydrate coingestion delays dietary protein digestion and absorption but does not modulate postprandial muscle protein accretion. J Clin Endocrinol Metab 99: 2250-2258, 2014. doi:10.1210/jc.2013-3970.

9. Gorissen SHM, Trommelen J, Kouw IWK, Holwerda AM, Pennings B, Groen BBL, Wall BT, Churchward-Venne TA, Horstman AMH, Koopman R, Burd NA, Fuchs CJ, Dirks ML, Res PT, Senden JMG, Steijns JMJM, de Groot LCPGM, Verdijk LB, van Loon LJC. Protein type, protein dose, and age modulate dietary protein digestion and phenylalanine absorption kinetics and plasma phenylalanine availability in humans. J Nutr In press. doi:10.1093/jn/nxaa024.

10. Goto K, Oda H, Morioka S, Naito T, Akema T, Kato H, Fujiya H, Nakajima Y, Sugiura T, Ohira Y, Yoshioka T. Skeletal muscle hypertrophy induced by low-intensity exercise with heat-stress in healthy human subjects. Jpn J Aerosp Environ Med 44: 13-16, 2007.

11. Goto K, Oda H, Kondo H, Igaki M, Suzuki A, Tsuchiya S, Murase T, Hase T, Fujiya H, Matsumoto I, Naito H, Sugiura T, Ohira Y, Yoshioka T. Responses of muscle mass, strength and gene transcripts to long-term heat stress in healthy human subjects. Eur J Appl Physiol 111: 17-27, 2011. doi:10.1007/s00421-010-1617-1.

12. Gregson W, Black MA, Jones H, Milson J, Morton J, Dawson B, Atkinson G, Green DJ. Influence of cold water immersion on limb and cutaneous blood flow at rest. Am J Sports Med 39: 1316-1323, 2011. doi: $10.1177 / 0363546510395497$.

13. Groen BB, Horstman AM, Hamer HM, de Haan M, van Kranenburg J, Bierau J, Poeze M, Wodzig WK, Rasmussen BB, van Loon LJ. Post-prandial protein handling: you are what you just ate. PLoS One 10: e0141582, 2015. doi:10.1371/journal.pone.0141582.

14. Hafen PS, Abbott K, Bowden J, Lopiano R, Hancock CR, Hyldahl RD. Daily heat treatment maintains mitochondrial function and attenuates atrophy in human skeletal muscle subjected to immobilization. $J$ Appl Physiol (1985) 127: 47-57, 2019. doi:10.1152/japplphysiol.01098.2018.

15. Hafen PS, Preece CN, Sorensen JR, Hancock CR, Hyldahl RD. Repeated exposure to heat stress induces mitochondrial adaptation in human skeletal muscle. J Appl Physiol (1985) 125: 1447-1455, 2018. doi:10.1152/japplphysiol.00383.2018.

16. Holwerda AM, Paulussen KJM, Overkamp M, Goessens JPB, Kramer IF, Wodzig WKWH, Verdijk LB, van Loon LJC. Dosedependent increases in whole-body net protein balance and dietary pro- 
tein-derived amino acid incorporation into myofibrillar protein during recovery from resistance exercise in older men. $J$ Nutr 149: 221-230, 2019. doi: $10.1093 / \mathrm{jn} / \mathrm{nxy} 263$.

17. Kakigi R, Naito H, Ogura Y, Kobayashi H, Saga N, Ichinoseki-Sekine N, Yoshihara T, Katamoto S. Heat stress enhances mTOR signaling after resistance exercise in human skeletal muscle. J Physiol Sci 61: 131-140, 2011. doi:10.1007/s12576-010-0130-y.

18. Kuligowski LA, Lephart SM, Giannantonio FP, Blanc RO. Effect of whirlpool therapy on the signs and symptoms of delayed-onset muscle soreness. J Athl Train 33: 222-228, 1998.

19. Mawhinney C, Jones H, Low DA, Green DJ, Howatson G, Gregson W. Influence of cold-water immersion on limb blood flow after resistance exercise. Eur J Sport Sci 17: 519-529, 2017. doi:10.1080/17461391.2017. 1279222 .

20. McGorm H, Roberts LA, Coombes JS, Peake JM. Turning up the heat: an evaluation of the evidence for heating to promote exercise recovery, muscle rehabilitation and adaptation. Sports Med 48: 1311-1328, 2018. doi:10.1007/s40279-018-0876-6.

21. Moore DR, Robinson MJ, Fry JL, Tang JE, Glover EI, Wilkinson SB, Prior T, Tarnopolsky MA, Phillips SM. Ingested protein dose response of muscle and albumin protein synthesis after resistance exercise in young men. Am J Clin Nutr 89: 161-168, 2009. doi:10.3945/ajen.2008.26401.

22. Naperalsky M, Ruby B, Slivka D. Environmental temperature and glycogen resynthesis. Int J Sports Med 31: 561-566, 2010. doi:10.1055/ s-0030-1254083.

23. Pournot H, Bieuzen F, Duffield R, Lepretre PM, Cozzolino C, Hausswirth C. Short-term effects of various water immersions on recovery from exhaustive intermittent exercise. Eur J Appl Physiol 111: 1287-1295, 2011. doi:10.1007/s00421-010-1754-6.

24. Rasmussen BB, Tipton KD, Miller SL, Wolf SE, Wolfe RR. An oral essential amino acid-carbohydrate supplement enhances muscle protein anabolism after resistance exercise. J Appl Physiol (1985) 88: 386-392, 2000. doi:10.1152/jappl.2000.88.2.386.

25. Rose S, Draper DO, Schulthies SS, Durrant E. The stretching window part two: rate of thermal decay in deep muscle following $1-\mathrm{MHz}$ ultrasound. J Athl Train 31: 139-143, 1996.

26. Skurvydas A, Kamandulis S, Stanislovaitis A, Streckis V, Mamkus G, Drazdauskas A. Leg immersion in warm water, stretch-shortening exercise, and exercise-induced muscle damage. J Athl Train 43: 592-599, 2008. doi: 10.4085/1062-6050-43.6.592.

27. Slivka D, Tucker T, Cuddy J, Hailes W, Ruby B. Local heat application enhances glycogenesis. Appl Physiol Nutr Metab 37: 247-251, 2012. doi:10.1139/h11-157.

28. Stadnyk AMJ, Rehrer NJ, Handcock PJ, Meredith-Jones KA, Cotter JD. No clear benefit of muscle heating on hypertrophy and strength with resistance training. Temperature (Austin) 5: 175-183, 2017. doi:10.1080/ 23328940.2017.1391366.

29. Stephens JM, Halson SL, Miller J, Slater GJ, Askew CD. Influence of body composition on physiological responses to post-exercise hydrotherapy. J Sports Sci 36: 1044-1053, 2018. doi:10.1080/02640414.2017. 1355062.

30. Tamura Y, Matsunaga Y, Masuda H, Takahashi Y, Takahashi Y, Terada S, Hoshino D, Hatta H. Postexercise whole body heat stress additively enhances endurance training-induced mitochondrial adaptations in mouse skeletal muscle. Am J Physiol Regul Integr Comp Physiol 307: R931-R943, 2014. doi:10.1152/ajpregu.00525.2013.

31. Tang JE, Manolakos JJ, Kujbida GW, Lysecki PJ, Moore DR, Phillips SM. Minimal whey protein with carbohydrate stimulates muscle protein synthesis following resistance exercise in trained young men. Appl Physiol Nutr Metab 32: 1132-1138, 2007. doi:10.1139/H07-076.

32. Trommelen J, Holwerda AM, Kouw IW, Langer H, Halson SL, Rollo I, Verdijk LB, VAN Loon LJ. Resistance exercise augments postprandial overnight muscle protein synthesis rates. Med Sci Sports Exerc 48: 2517-2525, 2016. doi:10.1249/MSS.0000000000001045.

33. Vaile J, Halson S, Gill N, Dawson B. Effect of hydrotherapy on recovery from fatigue. Int J Sports Med 29: 539-544, 2008. doi:10.1055/s-2007989267.

34. Vaile J, Halson S, Gill N, Dawson B. Effect of hydrotherapy on the signs and symptoms of delayed onset muscle soreness. Eur J Appl Physiol 102: 447-455, 2008. doi:10.1007/s00421-007-0605-6.

35. Versey NG, Halson SL, Dawson BT. Water immersion recovery for athletes: effect on exercise performance and practical recommendations. Sports Med 43: 1101-1130, 2013. doi:10.1007/s40279-013-0063-8.

36. Viitasalo JT, Niemelä K, Kaappola R, Korjus T, Levola M, Mononen HV, Rusko HK, Takala TE. Warm underwater water-jet massage improves recovery from intense physical exercise. Eur J Appl Physiol Occup Physiol 71: 431-438, 1995. doi:10.1007/BF00635877.

37. Witard OC, Jackman SR, Breen L, Smith K, Selby A, Tipton KD. Myofibrillar muscle protein synthesis rates subsequent to a meal in response to increasing doses of whey protein at rest and after resistance exercise. Am J Clin Nutr 99: 86-95, 2014. doi:10.3945/ajcn.112.055517.

38. Yoshihara T, Naito H, Kakigi R, Ichinoseki-Sekine N, Ogura Y, Sugiura T, Katamoto S. Heat stress activates the Akt/mTOR signalling pathway in rat skeletal muscle. Acta Physiol (Oxf) 207: 416-426, 2013. doi:10.1111/apha.12040.

39. Zak RB, Hassenstab BM, Zuehlke LK, Heesch MWS, Shute RJ, Laursen TL, LaSalle DT, Slivka DR. Impact of local heating and cooling on skeletal muscle transcriptional response related to myogenesis and proteolysis. Eur J Appl Physiol 118: 101-109, 2018. doi:10.1007/s00421017-3749-z. 